\title{
THE AWARENESS OF SHARIA FINANCIAL LITERACY IN THE QUARTERLIFE CRISIS PHASE
}

\author{
Alfina Rahmatia \\ rahmatiaalfina@gmail.com
}

\begin{abstract}
Nowadays, there are enormous challenges toward this era, especially the young generation between 20 and first 30 years old who will face quarterlife crisis phase in which one of the causes is literate or not literate to finance. The grand objective of this research is to analyze gender, income per month and marital status toward the awareness level to sharia financial literacy in the quarterlife crisis phase for IAIN Palangka Raya Alumni on 2010-2015. Primary data applied in this study are compiled from questionnaire and interviews with the mixed methods. This research uses multiple regression with SPSS application, while the interview data uses descriptive analysis. The result reveals that gender and income per month have no significant influence to the awareness level of sharia financial literacy, but marital status has a significant influence to the awareness level of sharia financial literacy for IAIN Palangka Raya Alumni on 20102015.
\end{abstract}

Keywords: Sharia financial literacy, Awareness, Quarterlife crisis phase

\section{Introduction}

Financial literacy has a strong relation with financial inclusion. In general, the approach through a national strategy includes 3 (three) aspects, namely the provision of appropriate service facilities, the provision of suitable products, responsible finance through financial education and consumer protection (BI, 2019). In the 2016, financial inclusive policies in Indonesia have been formulated by Financial Services Authority Regulation (OJK, 2016). Inclusive finance is growing rapidly because it has close links with poverty and social phenomena in the financial sector.

In Indonesia, only about $52 \%$ of the population has access to formal financial services; but only $21 \%$ of the poor population is served. Then, in the financial sector in the form of savings and loans for example. About a third of the population has no savings at all, and bank credit reaches only $17 \%$ of the population, while Microfinance Institutions reach only about 10\%. The data was obtained from the World Bank in 2012 (Widianto, 2014). Within eight years, in 2018 only $48 \%$ of Indonesia's population had an account with a formal financial institution (Bank, 2019). That means there is no significant development in formal financial services in Indonesia in eight years. 


\section{Vol 7 No 2: Agustus 2020. 45-62 \\ ISSN: 2460-9889 (Cetak) \\ ISSN: 2580-3565 (Online)}

Despite an increase in the level of financial inclusion from 2013 by $59.74 \%$ to $67.82 \%$ in 2016, knowledge of inclusive finance is still very low in Indonesian society (Akyuwen \& Mangowal, 2017). Then it needs to be improved by conducting activities or training on financial inclusion in a sustainable manner to the community, and providing assistance so that the quality of training output can be maintained. In addition to the training program which is an outreach, it is also necessary for the regional government to collaborate with banks and the Financial Services Authority to expand access to public financial services, including increasing public awareness of financial literacy (Ma'ruf \& Desiyana, 2015).

Financial literacy is essential but it does not arise in any level of education in Indonesia. Thus, it can be said that educational background has no relation to the personal financial knowlage and management. According to Robert T. Kiyosaki, the financial literacy is the fundamental competency to peruse and comprehend financial accounts and to manage cash flow. Every people must know how financial planning from the income he has (Kiyosaki, 2000). In addition to knowing the outflows and outflows of money that we have, also to escape something unexpected.

Nowadays awareness of financial literacy is no longer rare to be discussed, studied and researched. Financial literacy becomes very important not only for employees, but also for each individual especially in dealing with complex economic conditions. There are even studies that say that there is a very strong relationship between financial literacy and one's way of life (Gaberlavage, 2009).

According to the 2013 Indonesian Financial Literacy National Survey, it showed that the level of financial literacy of the Indonesian people was $21.84 \%$ with the share for banks classified as well literate at $21.8 \%$, sufficient literate at $75.44 \%$, less literate at $2.04 \%$ and not literate of $0.73 \%$, with a level of use of banking financial products and services of $57.28 \%$. This figure illustrates that the level of financial literacy of Indonesian people is still low (OJK, 2013). Then in 2016, financial literacy in Indonesia increased to $29.66 \%$. While sharia financial literacy is still low at $8.11 \%$ (OJK, 2016).

Islamic financial literacy that is closely related to Islamic economics notes that based on the 2017 Global Islamic Economic Index which measures the development of Islamic economies around the world, places Indonesia at number 9, far behind Malaysia which ranks first. The reason for the low ranking of Indonesia on the Global Islamic Economic Index is the low sharia financial literacy of the Indonesian (Wahyuni, 2016).

The population in Indonesia in 2018 will reach 265 million. The number consisted of 133.17 million men and 131.88 million women. According to age groups, the population that is still classified as children (0-14 years) reaches 70.49 million people or around $26.6 \%$ of the total population. For the population in the productive age category (14-64 years old) 179.13 million people (67.6\%) and the elderly population 65 and over 85.89 million people 


\section{Vol 7 No 2: Agustus 2020. 45-62 \\ ISSN: 2460-9889 (Cetak) \\ ISSN: 2580-3565 (Online)}

(5.8\%) (Data Publish, 2018). Populations of productive age make up the majority of the population.

According to Thorspecken, the quarterlife crisis is a growing phenomenon that occurs in American society that affects many young adults in their 20 s and 30s. This is a period of stress, instability and major changes in life. A quarter-life crisis occurs when many young adults feel doubtful about their future and feel trapped in their life choices (M.Thorspecken, 2005). Seeing the previous data on the population in Indonesia which is dominated by productive age, which means that at the age of 20 and 30 years it occupies around $20 \%$ of the percentage of the population of Indonesia, then the role of that age is very crucial given the existence of the quarterlife crisis phenomenon.

Oliver Robinson in his article entitled How to Turn Your Quarterlife Crisis into Quarterlife Catalyst in 2017, one of the senior lecturers in the field of psychology at Greenwich University said that $60 \%$ of individuals aged 25 - 35 years experience difficulties in managing their finances, and 30\% more do more expenses than income. This causes financial crisis in their lives even though the age has entered a productive age which will indirectly also affect the level of public awareness of shari'ah financial literacy in particular because the presence of the Islamic economic system in financial institutions gives a new atmosphere.

The Islamic economic system appears at a junction, and increasingly shows its existence among former conventional economic systems, so it is very feasible to be developed. This can be proven when the economic crisis in Indonesia in 1998, when all conventional banks went bankrupt, Islamic bank remained upright without being affected by the crisis. The phenomenon became the public spotlight until today. Another part which forms the Islamic economic system turned the spotlight is the characteristics that are implement in the Islamic economic system, as like as the profit-sharing system which removes interest (Muqorobin, 2008).

The younger generation, especially at the age of quarterlife, faces great challenges regarding managing their own finances, especially in the face of a growing era like today. However, there is not yet one subject or special training that young people can take to support it from elementary school to university, so it is not uncommon for them to feel stressed and depressed. Including the alumni of IAIN Palangka Raya through a search by the author through free interviews, many of them are pressured by thoughts of the future such as a career that begins with a lack of understanding of financial literacy awareness.

For this reason, the author takes the title "The Analysis of Factors Affecting the Awareness Level of Sharia Financial Literacy in the Quarterlife Crisis Phase of IAIN Palangka Raya Alumni Period 2010 - 2015."

\section{Literature Review}

Many experts provide theories about consciousness, including Carl G Jung and Sigmeud Freud. According to Carl G Jung, consciousness consists of three interconnected 


\section{Vol 7 No 2: Agustus 2020. 45-62 \\ ISSN: 2460-9889 (Cetak) \\ ISSN: 2580-3565 (Online)}

systems, namely the consciousness or ego, the personal unconscious and the collective unconscious. Meanwhile, according to Sigmeud Freud, consciousness consists of conscious thoughts and unconscious thoughts, both of which are triggered by motivation from within and outside the individual (Ismail, 2009). According to Paul B. Horton, the definition of society is a group of people who are relatively independent by living together for a long time, living in a certain area with the same culture, and most of the activities in that group (Muin, 2013).

The implementation of education in order to improve public finances is very necessary because based on a survey conducted by the OJK in 2013, the level of financial literacy of the Indonesian population is divided into four parts, namely (OJK, 2013): 1) Well literate (21.84\%), namely having knowledge and confidence about financial service institutions and financial service products, including features, benefits and risks, rights and obligations related to financial products and services, and having skills in using financial products and services. 2) Sufficient literate (75.69\%), possessing knowledge and confidence about financial service institutions and financial products and services, including features, benefits and risks, rights and obligations related to financial products and services. 3) Less literate $(2.06 \%)$, only have knowledge of financial service institutions, financial products and services. 4) Not literate $(0.41 \%)$, do not have knowledge and confidence in financial service institutions and financial products and services, and do not have skills in using financial products and services.

Financial literacy has long-term goals for all groups of society, namely (OJK, 2016): Increase the literacy of someone who was previously less literate or not literate to become well literate and Increase the number of users of financial products and services.

In order for the wider community to determine financial products and services according to their needs, the community must properly understand the benefits and risks, know their rights and obligations, and believe that the selected financial products and services can improve people's welfare. For the community, financial literacy provides great benefits (OJK, 2016): able to select and utilize financial products and services as needed; have the ability to do financial planning better and avoid investing activities in unclear financial instruments.

Financial literacy also provides great benefits for the financial services sector. Financial institutions and the public need each other so that the higher the level of public financial literacy, the more people will take advantage of financial products and services (OJK).

A person can be said to be "literate" in Islamic finance if he/ she knows Islamic financial products and services, is able to distinguish between Islamic banks and conventional banks and is able to control himself in making economic decisions according to sharia. Believing in Divine teachings, without usury, without haram investments, without gharar (uncertainty), without maysir (gambling/ speculation), all risks and financing based on 
real assets are the key principles of Islamic finance (Abdullah, 2012). As stated by Mohamad Azmi Abdullah (2017) regarding Islamic financial literacy, "Islamic financial literacy can be defined as the ability to understand finance based on sharia compliance. This should be an issue of concern to Muslim students. Muslims must seek to understand Islamic finance because it is a religious duty. Using the conventional financial system is certainly sinful for Muslims." This means that the ability regarding Islamic financial literacy is the obligation of every Muslim because of religious obligations that must be obeyed.

There are four aspects to financial literacy, namely (An Analysis of Personal Financial Literacy Among College Students, 1998): General personal finance knowledge, Savings and borrowings), such as use of credit cards, Insurance such as life insurance and motor vehicle insurance and Investment, knowledge of market interest rates, mutual funds and investment risks.

According to Alexander Robbins and Abby Wilner in the book Quarterlife Crisis: The Unique Challenge of Life in Your Twenties, said that the quartelife phase or quarterlife crisis is basically a period of anxiety and uncertainty that often accompanies the transition to adulthood (2001). Quarterlife is a phenomenon experienced by many young adults in their 20s and early 30s. It is also a response to tremendous instability, constant change, too many choices, a sense of helplessness, and panic (Quarterlife Crisis: Then Unaddressed Phenomenon, 2005).

A quarterlife crisis can occur for a variety of reasons, such as identity confusion, frustration with a relationship, the world of work, finding a suitable job or career, insecurity about the future, disappointment over something, pressure from family and peers and so on (2013). Robinson said there were four phases that individuals went through in the quarterlife crisis, "The four levels of analysis are: person in environment, identity, motivation, and affect-cognition. The person in environment level considers the systemic changes in physical locations, relationships, and work commitments. Identity focuses on changes in a person's subjective sense of personhood, while the motivation level focuses on how a person describes their orientation towards goals, values and action. Affectcognition describes the dominant affective and ruminative quality of a particular stage."

From previous research, the writer makes a distinction between research related to the research that the author is doing. Among these are: Research conducted by Bharat Singh Thapa and Raj Surendra Nepal with the title "Financial Literacy in Nepal: Survey Analysis from Higher Education" shows that most students have a level of basic financial knowledge but they lack understanding of credit, taxes, market share, financial statements, and insurance (Thapa \& Nepal, 2015).

Research conducted by Sekar and Gowri entitled "Financial Literacy Study and Its Determinants among Gen Y Employees in Coimbatore City" shows that the level of financial literacy varies significantly among respondents based on various demographic and socio-economic factors. Gender, education, income, marital status has a significant effect 


\section{Vol 7 No 2: Agustus 2020. 45-62 \\ ISSN: 2460-9889 (Cetak) \\ ISSN: 2580-3565 (Online)}

on financial literacy, while age has no influence. It states that the level of financial literacy is low among Gen Y employees in the city of Coimbatore and actions that need to be taken by the government to raise awareness about matters relating to finance (Sekar \& Gowri, 2015).

Research the title "Financial Literacy Levels at the Faculty of Economics written by Farah Margaretha and Reza Arief Pambudhi states that the level of financial literacy at the Faculty of Economics S-1 students at the Trisakti University as a whole is in the low category, where gender, age, GPA and parental income have an influence on student financial literacy. The year of admission, place of residence, and parental education has no influence on financial literacy. Personal finance education for students is the proposed solution (Margaretha \& Pambudhi, 2015). The research "Financial Literacy Levels among STIE Musi Students" describes that the study of financial literacy in high schools is not enough to provide a deep understanding of students both from the aspects of personal finance, savings, insurance and other financial products (Mendari \& Kewal, 2013). The research conducted by the author will explore the level of awareness of Islamic financial literacy in the community which focuses on the age that is entering the quarterlife phase by taking the object of IAIN Palangka Raya alumni from 2010 to 2015.

\section{Research Method}

The data used in this study are primary data taken directly from the study location. This research uses a mixed method, meaning that this study mixes quantitative and qualitative methods. There are three basic methods in mixed methods namely; convergent parallel mixed method, explanatory sequential mixed method, and exploratory sequential mixed method (Sumanto, 2014). This study uses a convergent parallel method in which the authors collect qualitative and quantitative data, analyze them separately, and compare the results to determine: whether there are findings that confirm each other (Creswell, 2016).

The population in this study is the number of Palangka Raya IAIN alumni who graduated from 2010 to 2015 from all majors as many as 1642 alumni. The sample is the process of selecting a number of research objects for research that represents the population. This research uses Slovin formula (2019) to determine the sample size from the available population size, 94.26 samples were obtained or rounded to 94 samples.

In this study, the interview technique used was a semi-structured interview. The questions asked are open but there are still restrictions in accordance with the theme and flow of the conversation. The purpose of semi-structured interviews is to understand people's awareness firsthand (Herdiansyah, 2010).

There are 50 questions in the questionnaire in this study. There are five specific questions about financial literacy; individual knowledge, investment, insurance, savings and loans, and knowledge of financial institutions where all aspects refer to Islamic economics.

The data that has been obtained from the questionnaire, before processing it must be done in advance the validity test to test how valid the questions raised in the 
questionnaire with the variables studied (Algifari, 2015). This study uses SPSS version 15.0 to determine the construct validity. The construct validity is to show that the measurement instruments in the questionnaire measure validly as indicated by strong correlations with the variables in the study. The validity test in this study uses the corrected item correlation technique, in making the decision is if $\mathrm{r}$ count $>\mathrm{r}$ table can be said to be valid, but conversely if $\mathrm{r}$ count $<\mathrm{r}$ table then it is said to be invalid. After being found valid or not, a significant test using $\mathrm{r}$ tables can be said to be significant at the 0.05 or $5 \%$ level (Abdillah \& Hartono, 2015).

\section{Result and Discussion}

Questions listed on the questionnaire must be known whether valid or not valid through the corrected item correlation column in the SPSS 16 application. In this study the reliability measurement is done by looking at the Cronbach alpha value. If the Cronbach alpha value is greater than 0.70 then the instrument can be said to be reliable, so even if Cronbach alpha is smaller than 0.70 then the instrument is declared not reliable. All research instruments are said to be reliable because what Cronbach alpha value is at a value greater than 0.70 , so there is no research instrument that must be deleted.

\section{Regression Analysis}

This study examines the effect of each independent variable, namely gender, marital status, and income permonth on the dependent variable, namely the level of sharia financial literacy in Palangka Raya IAIN alumni from the period 2010 - 2015.

The first analysis conducted is to test the coefficient of determination in the $\mathrm{R}$ square column. Through the table below it can be seen that the $\mathrm{R}$ square of 0.075 which means that the variables of gender, marital status and income per month can explain the level of awareness of Islamic financial literacy of 7.5 percent, the rest is influenced by variables outside the model. $\mathrm{R}$ square value of 7.5 percent can be said to be very small.

This can occur one of the reasons because it is still rare and lack of research that discusses financial literacy, especially shariah financial literacy. In fact, the Financial Services authority was just beginning to bloom or started to do research on Islamic financial literacy in 2016.

Table 3

Determination Coefficient Test Results

\begin{tabular}{|l|l|l|l|l|l|}
\hline $\begin{array}{l}\text { Mode } \\
1\end{array}$ & $\mathrm{R}$ & $\mathrm{R}$ Square & $\begin{array}{l}\text { Adjusted } \\
\mathrm{R} \text { Square }\end{array}$ & $\begin{array}{l}\text { Std. Error of } \\
\text { the Estimate }\end{array}$ & $\begin{array}{l}\text { Durbin-Watson } \\
1\end{array}$ \\
$.274 \mathrm{a}$ & .075 & .044 & 16.818 & 1.830 \\
\hline $\begin{array}{l}\text { a. Predictors: (Constant), income, marital status, gender } \\
\text { b. Dependent Variable: total_all }\end{array}$
\end{tabular}

Source:Developed for the research 
After tested the coefficient of determination, the next is the $t$ test to see how partially each independent variable affects the dependent variable. Here are the results of the $t$ test by looking at the probability value (Sig.) On each independent variable.

\section{Table 4}

Test t Result

\begin{tabular}{|c|c|c|c|c|c|}
\hline \multirow[b]{2}{*}{ Model } & \multicolumn{2}{|c|}{$\begin{array}{l}\text { Unstandardized } \\
\text { Coefficients }\end{array}$} & \multirow{2}{*}{$\begin{array}{c}\text { Standardized } \\
\text { Coefficients } \\
\text { Beta }\end{array}$} & \multirow[b]{2}{*}{$\mathbf{t}$} & \multirow[b]{2}{*}{ Sig. } \\
\hline & B & $\begin{array}{l}\text { Std. } \\
\text { Error }\end{array}$ & & & \\
\hline 1 (Constant) & 118.190 & 6.510 & & 18.155 & .000 \\
\hline Gender & -.911 & 3.831 & -.027 & -.238 & .813 \\
\hline Marial Status & 8.215 & 3.469 & .250 & 2.363 & .020 \\
\hline $\begin{array}{l}\text { Income } \\
\text { permonth }\end{array}$ & 1.973 & 2.949 & .075 & .669 & .505 \\
\hline
\end{tabular}

Source: Developed for the research

In the table above it can be seen that the gender variable significant value of 0.813 is greater than 0.05 , and income per month is significant value of 0.505 greater than 0.05 . So it can be concluded that the variables of gender and income permonth do not significantly affect the level of Islamic financial literacy. In contrast to the marital status variable at a significant rate of 0.020 smaller than 0.05 . So it can be concluded that the marital status influences the level of awareness of Islamic financial literacy of IAIN Palangka Raya alumni period 2010-2015 significantly.

Then the F test is used to see whether there is a stimulant effect on the independent variable on the dependent variable. In the table below it can be concluded that there is a positive and significant effect on the independent variable on the dependent variable because the F significance level of 0.01 is smaller than 0.05 .

\section{Table 5}

Test F Result

\begin{tabular}{|c|c|c|c|c|c|c|}
\hline & Model & $\begin{array}{l}\text { Sum of } \\
\text { Squares }\end{array}$ & df & $\begin{array}{l}\text { Mean } \\
\text { Square }\end{array}$ & $\mathbf{F}$ & Sig. \\
\hline 1 & Regression & 2067.561 & 3 & 689.187 & 2.437 & $.070^{\mathrm{a}}$ \\
\hline & Residual & 25456.364 & 90 & 282.848 & & \\
\hline & Total & 27523.926 & 93 & & & \\
\hline & redictors: $(\mathrm{C}$ & stant), incom & marital & atus, gender & & \\
\hline & ependent I & able: total_al & & & & \\
\hline
\end{tabular}

Source: Developed for the research 


\section{Vol 7 No 2: Agustus 2020. 45-62 \\ ISSN: 2460-9889 (Cetak) \\ ISSN: 2580-3565 (Online)}

\section{Discussion}

In the discussion of research results based on the above data analysis, researchers will combine them with the data obtained from the results of in-depth interviews. The following discussion of research results based on the independent variable of the dependent variable:

\section{The Influence of Gender on Sharia Financial Literacy}

In table $4.5 \mathrm{t}$ test results, we can conclude that gender does not have a significant effect on the level of sharia financial literacy of Palangka Raya IAIN alumni in 2010-2015, due to the probability value of sig. amounting to 0.813 is greater than 0.05 .

The results of gender research have no effect on the level of sharia financial literacy of Palangka Raya IAIN alumni in 2010-2015 showing that men and women have the same opportunities and abilities in terms of sharia financial literacy. As in the current era of globalization and modernization where gender equality is the main focus in the development of the State, both in terms of economic, social, and political (Flood, 2018). This happens because the times have changed and developed rapidly, in contrast to ancient times when discrimination against women is still limited in scope and gestures (Nyman, Reinikainen, \& Eriksson, 2018).

The presumption and research that says that women are more financially manageable than men are now firmly denied (Potrich, Vieira, Kirch, 2017). This statement is reinforced by research which says that a person's financial literacy has no effect on what gender. However, there are studies that argue that women's financial literacy in marginal and remote areas is still very small because it is influenced by their educational backgrounds (Haider, Changchun, Akram, \& Hussain, 2018). The study was refuted again by research conducted by Andrej Cupák, Pirmin Fessler, Alyssa Schneebaum, and Maria Silgoner who believed that the level of financial literacy for women in developed countries was very high, in contrast to developing countries such as Bangladesh, Indonesia, Malaysia and Pakistan. But women's participation in economic development continues to increase every year (Cupák, Fessler, Schneebaum, \& Silgoner, 2018).

However, this is mediated by research which states that gender equality depends on the socio-cultural environment of a region (Nyman, Reinikainen, \& Eriksson, 2018). Including the equality in terms of Islamic financial literacy. In the Islamic view, men and women are already found in the Holy Qur'an regarding matters and obligations and equality in the eyes of Allah SWT, except faith and piety. As in the surah Al-Qur'an Surah Al-Hujurat verse 13.

Looking at the data generated from in-depth interviews, respondents with the initials De said that after marriage, he and his wife had a proportional division of tasks, such as the wife managing finances and the husband made a living, where in his single period, De was used to also record personal finances and investing. De never forbids his wife to work or 


\section{Vol 7 No 2: Agustus 2020. 45-62 \\ ISSN: 2460-9889 (Cetak) \\ ISSN: 2580-3565 (Online)}

study again, because according to De, it is the intelligence of women who will be inherited by their children, including intelligence in matters of financial management (De, 2019).

This is consistent with Si's statement that he as a wife became the minister of finance in the household. The person is permitted to work for a living and may also receive the highest level of education by her husband, without forgetting the nature and obligations of his wife and young mother (Si, 2019). The statement is in accordance with research conducted by Jing Zou and Xiaojun Deng said that when men and women have the same roles and rights in controlling and managing finances so that it affects the level of financial literacy and decision making, especially if they are already married (Si, 2019).

\section{The Influence of Marital Status on Sharia Financial Literacy}

From the results of the $t$ test in table 4.5 we can know that marital status has a significant effect on the level of sharia financial literacy of Palangka Raya IAIN alumni in 2010 - 2015. This is due to the probability value of sig. is at a value of 0.02 smaller than 0.05 .

Marriage makes someone more open and literate towards the future, including in terms of managing personal finances. Especially at the age of quarterlife where according to Oliver Robinso, $60 \%$ of individuals find it difficult to manage their finances, except when getting more responsibilities such as getting married and having children. Young people who choose to get married at a young age, when faced with the phenomenon of quarterlife crisis will be easier to control and adapt if the communication in their marriage goes well and smooth, and continues to remember that the purpose of marriage is not only to continue the offspring, but also to share affection and responsibility, and happiness and suffering joyfully (Gonczarowski, Nisan, Ostrovsky, \& Rosenbaum, 2016).

This is in line with research conducted in the City of Coimbatore by Sekar M and Gowri $\mathrm{M}$ who said that marital status has a significant influence on financial literacy in which the government should have a strong role in educating financial literacy to young people so that they will be more alert in the future. manage finances when married. No longer because of the demands of responsibility, but has become a habit and characteristic (Sekar \& Gowri, 2015).

In contrast to Sekar M and Gowri M, on the other hand there are studies that argue that marital status has no effect on a person's literacy level, especially at the age of quarterlife (Sekar \& Gowri, 2015). This research reveals that what influences the level of financial literacy is seen from all aspects. Not a few people understand basic financial knowledge, but still lack understanding of the aspects of investment, insurance, saving and borrowing, as well as other existing financial institutions. Plus in this day and age where there is digital fintech to facilitate all kinds of transactions that demand everyone to be more familiar with financial literacy through all aspects. If someone lacks awareness in financial literacy, whether married or unmarried, it will not affect his habits (Zou \& Deng, 2019). 


\section{Vol 7 No 2: Agustus 2020. 45-62 \\ ISSN: 2460-9889 (Cetak) \\ ISSN: 2580-3565 (Online)}

This was emphasized in the in-depth interview, the initials of $\mathrm{Ba}$ as a single person still could not record regularly his personal finances, as well as lack of knowledge about investment and insurance, even feeling less trusting in Islamic financial institutions because the procedural system was complicated or did not facilitate, cash withdrawal services that are difficult to find, and there are several Islamic banks with less friendly services and customer service explanations that are difficult to understand. $\mathrm{Ba}$ also explained that the online wallet application and online investment are still not fully understood, limited to just knowing or never hearing. The only online wallet that $\mathrm{Ba}$ has ever used is the online wallet application from online motorcycle taxis (Ba, 2019).

However, the respondent with the initials Si said that after marriage, he felt there were financial demands that he must understand for his household life. So inevitably he must be aware and understand everything before it is too late, for him slowly but surely. This was also helped by their partners in learning about Islamic finance. Even though until now Si still has no Islamic investment and Islamic insurance, Si and his partner believe to save and borrow at Islamic banks until now (Si, 2019).

That is also what Han said, a woman who works as a young entrepreneur with an income of more than seven million rupiah per month. Han, who is about to release his bachelor, believes there are significant changes in financial management when he knows he is getting married. Han began to learn massively and understand what is a stock investment and Islamic mutual funds, and ask directly to Islamic insurance companies about the mechanisms and systems that are in it. For $\mathrm{Ha}$, before getting married, Han would rather spend his money on hobbies and lifestyle, with no clear purpose where to earn income from his work (Ha, 2019).

This is in line with research conducted by Chris Brooks, Ivan Sangiorgi, Carola Hillenbrand, and Kevin Money who stated that husband and wife become more financially literate when married and take decisions together in household finances, especially if they come together to financial advicer regarding financial management, from financial planning to financial risk taking (Brooks, Sangiorgi, Hillenbrand, \& Money, 2019).

There are even studies that say that the level of children's financial literacy is influenced by how both parents educate and provide an understanding of saving and borrowing early on (Moreno-Herrero, Salas-Velasco, \& Sánchez-Campillo, 2018). So that children can make their own financial programs as taught by their parents, making the child more ready to face challenges, especially in the times of a life crisis (Hanson \& Olson, 2018).

That means it can be concluded that the marital status of a person has a strong influence on the high and low levels of financial literacy of individuals and households. When a husband and wife can perform their rights and obligations well and have smooth and good communication, including in their awareness of sharia financial literacy and have become a habit or character in the household, then this will affect the ability of sharia financial literacy of children indirectly since early stage. Even someone who is about to get 


\section{Vol 7 No 2: Agustus 2020. 45-62 \\ ISSN: 2460-9889 (Cetak) \\ ISSN: 2580-3565 (Online)}

married (proposed), according to respondents on behalf of Han initials, he can feel a drastic change in the way he manages personal finances.

\section{The Influence of Income permonth on Sharia Financial Literacy}

The regression test results in table 4.5 show that the probability value is 0.82 greater than 0.05 or it can be concluded that income permonth does not significantly influence the level of sharia financial literacy of Palangka Raya IAIN alumni in 2010-2015 in the phase quarterlife crisis.

Based on the data in the form of results from 94 samples, the average income permonth of Palangka Raya IAIN alumni in the period 2010 - 2015 is in the range of 1,000,000 - 3,000,000 rupiah, or according to the Central Kalimantan Provincial Minimum Wage (UMP) of Rp 2,615,735, and Regency or City Minimum Wage, which is Rp 2,701,004, although there may still be some that are below the UMP or UMK because it says only the range.

Speaking of income, in Indonesia itself has a different UMR in each region. UMR stands for Regional Minimum Wage, based on Minister of Manpower Regulation Number: PER 01/MEN/1999 regarding "Minimum Wages", UMR is the lowest monthly wage consisting of basic wages including fixed allowances that apply in one province. UMR has a great influence on the unemployment rate. For example, when the minimum wage in the capital city of Jakarta was raised from 2.2 million rupiah to 2.4 million rupiah, as a result employers or companies relocated to places with lower UMR levels to avoid rising labor costs. In microeconomics, opponents of minimum wages argue that minimum wages are not a solution to the fight against poverty. But it causes unemployment, many students drop out of school, workers become poorly trained. These findings contradict other studies which say that the higher a person's income, the higher the level of financial literacy he has.

Research conducted by Antonia Grohmann found findings about high incomes for urban communities have an effect on financial literacy and financial decision making, in contrast to people in remote areas with income below the minimum wage have a low literacy level and tend to be afraid of taking financial risks, like investment and insurance. That is because the lack of socialization or equitable learning about financial literacy, understanding or training about financial literacy only occurs in big cities, does not spread to remote areas (Grohmann, 2018).

On the other hand, research conducted by Monica Paiella that said that a person's income has no effect on the level of financial literacy, especially for young people both high and low income, most of them have high expectations regarding financial planning and management but still lack of awareness in financial literacy due to lack of knowledge and socialization gained, not only in school or college, but also from the government. Young people's expectations are broken when they have to face directly how to plan and manage finances, someone tends to be shocked and this is what then becomes one of the causes of the emergence of the quarterlife crisis phenomenon (Paiella, 2015). Young people who have 


\section{Vol 7 No 2: Agustus 2020. 45-62 \\ ISSN: 2460-9889 (Cetak) \\ ISSN: 2580-3565 (Online)}

faced many surprises for the fact that is not in accordance with their expectations, plus found that their financial turmoil, making someone stressed and often lead to depression and suicide. This sounds terrible, but it actually happens.

The results of this study are in line with the results of research conducted by Oscar Stolper that the income of a person and household does not affect the level of financial literacy, but it is the nature or personality of a person that determines, such as the desire to go to a financial advisor who comes from personal awareness where it depends on the environment social or household (Stolper, 2017).

Then, the results of in-depth interviews with the initials Ul, a private employee as well as a graduate student, stated that regardless of the amount of salary received, he was routine in recording and financial planning. Although not once a day, but once a month that is certain, because from childhood, his parents have taught how to manage finances, plus UI who currently works as a staff in the financial division. Based on his remarks, UI also has Islamic mutual funds and savings accounts in Islamic banks, although the salary is transferred using conventional banks, but in saving and borrowing, UI prefers Islamic banks as one of its efforts to avoid usury and speculation, as well as helping in grounding the Islamic economy in Indonesia (UI, 2019).

This research is in line with what is said by $\mathrm{Ba}$, saying that the size of the income he has does not affect his ability to manage finances, even though there is already awareness and desire, but all that is only imagined in his mind without direct and consistent realization. His skeptical mind on Islamic financial institutions is one of the factors that makes $\mathrm{Ba}$ reluctant to carefully and painstakingly study how funds plan and manage finances. According to him, maybe if he was married one day the story would be different (Ba, 2019).

\section{Sharia Financial Literacy Level}

The level of awareness of Islamic financial literacy in Palangka Raya IAIN alumni in the period 2010 - 2015 in the quarterlife crisis phase when viewed from the results of the percentage formula index is 53 percent or in the neutral category. This can be a gift or a curse, a gift because another 7 percent can enter the good category, but it still needs 17 percent to reach the very good category. Can be a curse because 22 percent approach the category is not good.

From the results of the questionnaire, the average finding obstacles in knowing and understanding investment and insurance items. The results of this study are in line with research conducted by Gina Sakinah and Bagio Mudakir who conducted research on undergraduate students at Diponegoro University, Faculty of Economics and Business, said that although students have an economic education background, it does not directly affect their ability to recognize and understand investment and insurance, especially investment and insurance in Sharia (Sakinah \& Mudakir, 2018).

On the same side, the study said that the CPI and parents' income significantly influence the level of sharia financial literacy. This is in line with this research which shows 


\section{Vol 7 No 2: Agustus 2020. 45-62 \\ ISSN: 2460-9889 (Cetak) \\ ISSN: 2580-3565 (Online)}

that marital status influences the level of awareness of Islamic financial literacy in Palangka Raya alumni of the 2010-2015 period in the quarterlife crisis phase. Including respondents' answers in discussing the level of sharia financial literacy on gender, income per month and marital status which could be considered as neutral, because there are those who are used to managing, planning and managing their finances at Islamic financial institutions such as UI, some are still reluctant to aware and understand the sharia financial literacy like Ba.

This is in line with what was recently reported that according to the Financial Services Authority (OJK) assesses that the current young generation still has little understanding of finance or financial literacy. "Only 64.2 percent of students use financial products and services, but only 23.4 percent of students have the knowledge, skills or beliefs and even financial attitudes and behaviors," Tirta said in Menara Radius Prawiro. Mr. Tirta explained, young people are currently at risk of financial problems because they are not equipped with financial literacy. He further explained that young people with the status of students and students tend to have access to financial products offered, but they still have little understanding (Liputan6, 2019).

The age of quarterlife is close to millennial generation. A leader of a private multimedia company, Mr. Andy Nahil Gultom considers that finance is very important for the younger generation, especially millennials. He explained that the discussion of financial services is indeed very broad, but the most important thing to give to young people today is financial literacy. So that they can later plan or manage their finances, because the millennial generation of the productive middle class is always faced with a consumptive lifestyle so that a good understanding of finance is needed (Kompas, 2019).

Financial intelligence is one intelligence that must be possessed by everyone. Therefore, financial education should have been done early. For example, students, since they first enrolled in college and then became a student, not many of them are able to plan and manage their finances for at least one month, starting from the beginning of the month. So often we hear a lot of students who are upset at the end of the month, and choose to remain silent in their boarding house so they don't spend a lot of money. This is one proof that the level of public understanding of financial literacy is still low. It is not accompanied by financial education that goes hand in hand. This research can be a reflection and benchmark especially for IAIN Palangka Raya in terms of Islamic financial literacy. IAIN Palangka Raya can become a pioneer in the development of Islamic financial literacy in Indonesia through ongoing training or workshops for students, so that when they become alumni they can become resilient alumni in the quarterlife crisis phenomenon.

Generally, Indonesia which in the scope of Southeast Asia lags behind Malaysia. Even though the level of saving at a macro level in Indonesia ranks in the top 20, Finland also lags far behind in the 82nd figure worldwide. But the level of happiness of Finland is in the first position in the world, while Indonesia is far in the 96th position. That is once 


\section{Vol 7 No 2: Agustus 2020. 45-62 \\ ISSN: 2460-9889 (Cetak) \\ ISSN: 2580-3565 (Online)}

again why, this research is useful as the next regeneration for the development of financial literacy (Finlit, 2019).

\section{Conclusion}

From the findings and discussion and in answering the formulation of the existing problems, the following conclusions can be drawn: 1) The level of awareness of Islamic financial literacy in IAIN Palangka Raya alumni during the period 2010 - 2015 in the quarterlife crisis phase was in the neutral category of 53 percent. 2) Gender does not affect the level of awareness of Islamic financial literacy in Palangka Raya IAIN alumni from the period 2010 - 2015 in the quarterlife crisis phase. 3) Income permonth does not affect the level of awareness of Islamic financial literacy in IAIN Palangka Raya alumni during the period 2010 - 2015 in the quarterlife crisis phase. 4) Marital status influences the level of awareness of Islamic financial literacy in IAIN Palangka Raya alumni from 2010-2015 in the quarterlife crisis phase. 5) There is no significant effect between gender with the level of financial literacy of IAIN Palangka Raya alumni in the period 2010 - 2015, where the number sig. amounted to $0.677>0.05$. 6) There is a significant influence between marital status and the level of financial literacy of Palangka Raya IAIN alumni in the 2010-2015 period, where the number sig. of $0.03>0.05$. 7) There is no significant effect between income permonth and the level of financial literacy of IAIN Palangka Raya alumni in the period 2010 - 2015, where the number sig. amounted to $0.606>0.05$.

\section{Reference}

2019. [Online] February 13, 2019. http:/ / sciencing.com/slovins-formula-samplingtechniques-5475547.html.

A Stable Marriage Requires Communication. Gonczarowski, Yanni A., et al. 2016. 2016, Games and Economic Behaviour, p. 4.

A Study on Financial Literacy and Its Determinants among Gen Y Employees in Coimbatore City. Sekar and Gowri. 2015. 2015, Great Lakes Herald, pp. 34-45.

Abdillah, Willy and Hartono, Jogiyanto. 2015. Partial Least Square (PLS) - Alternative Structural Equation Modeling (SEM) dalam Penelitian Bisnis. Yogyakarta : Penerbit Andi, 2015.

Abdullah, Daud Vicary. 2012. Buku Pintar Kenangan Syariah. Jakarta : Zaman, 2012. Algifari. 2015. Analisis Regresi Untuk Bisnis dan Ekonomi. Yogyakarta : BPFE-Yogyakarta, 2015.

An Analysis of Personal Financial Literacy Among College Students. Chen, Haiyang and Volpe, Ronald P. 1998. s.l. : Financial Services Review, 1998.

Analisis Literasi Kenangan Mahasiswa S-1 Fakultas Ekonomika dan Bisnis Universitas Diponegoro Angkatan 2014-2017. Sakinah, Gina and Mudakir, Bagio. 2018. 2018, Jurnal Dinamika Ekonomi Pembangunan, p. 14.

Ba, Initial. 2019. Financial Literacy. [interv.] Alfina Rahmatia. June 11, 2019. 
Bank, World. 2019. Global Financial Index. [Online] February 13, 2019. http://globalfindex.worldbank.org.

Basuki, Agus Tri. 2015. Regresi dalam Penelitian Ekonomi dan Bisnis. Yogyakarta: Danisa Media, 2015.

BI. 2019. Keuangan Inklusif Indonesia. Bank Indonesia. [Online] February 13, 2019. https://www.bi.go.id/id/perbankan/keuanganinklusif/Indonesia/Contents/.

Creswell, John W. 2016. Research Design Pendekatan Kualitatif, Kuantitatif dan Campuran. Yogyakarta : Pustaka Pelajar, 2016.

2018. Data Publish. Katadata. [Online] November 11, 2018. https://databoks.katadata.co.id/datapublish/2018/05/18/2018-jumlah-pendudukindonesia-mencapai-265-juta-jiwa .

De, Initial. 2019. Financial Literacy. [interv.] Alfina Rahmatia. June 12, 2019.

Decomposing Gender Gaps in Financial Literacy: New International Evidence. Cupák, Andrej, et al. 2018. 2018, Economics Letters, p. 5.

Experience Wears The Trousers: Exploring Gender and Attitude to Financial Risk. Brooks, Chris, et al. 2019. 2019, Journal of Economic Behavior and Organization, p. 504.

Exploring Gender Effects in Intention to Islamic Mobile Banking Adoption: An Empirical Study. Haider, Muhammad Jamal, et al. 2018. 2018, Arab Economic and Business Journal, Holy Spirit University of Kaslik, p. 28.

Factors Determining Islamic Financial Literacy Among Undergraduates. Abdullah, Mohamad Azmi. 2017. Kuala Lumpur : Journal of Emerging Economies and Islamic Research, 2017, p. 70.

Factors that Influence The Level of Financial Literacy Among Young People: The Role of Parental Engagement and Students' Experiences with Money Matters. Moreno-Herrero, Dolores, SalasVelasco, Manuel and Sánchez-Campillo, José. 2018. 2018, Children and Youth Services Review, p. 347.

Financial Literacy and Family Communication Patterns. Hanson, Thomas A. and Olson, Peter M. 2018. 2018, Journal of Behavioral and Experimental Finance, p. 23.

Financial Literacy and Financial Behavior: Evidence from the Emerging Asian Middle Class.

Grohmann, Antonia. 2018. 2018, Pacific-Basin Finance Journal, p. 140.

Financial Literacy and Subjective Expectations Questions: A Validation Exercise. Paiella, Monica. 2015. 2015, Research in Economics, pp. 17-18.

Financial Literacy in Nepal: A Survey Analysis from Collage Students. Thapa, Bharat Singh and Nepal, Surendra Raj. 2015. Kathmandu : NRB Economic Review, 2015. Proseding 2nd International Conference. pp. 49-74.

Financial Literacy More Important Than Ever. Gaberlavage, George. 2009. s.l. : AARP International, 2009, Economic Security and Work Journal, p. 40. 
Financial Literacy, Housing Value and Household Financial Market Participation: Evidence from Urban China. Zou, Jing and Deng, Xiaojun. 2019. 2019, China Economic Review, pp. 62-63.

Finlit. 2019. [Online] August 10, 2019. http://www.finlit.mhfi.com.

Gender Equality: Engaging Men in Change. Flood, Michael. 2018. 2018, The Art of Medicine, pp. 1-2.

Ha, Initial. 2019. Financial Literacy. [interv.] Alfina Rahmatia. June 13, 2019.

Herdiansyah, Haris. 2010. Metodologi Penelitian Kualitatif untuk. Ilmu-ilmu Sosial. Jakarta : Salemba Humanika, 2010.

It Takes Two to Tango: Households' Response to Financial Advice and The Role of Financial

Literacy. Stolper, Oscar. 2017. 2017, Journal of Banking and Finance, pp. 22-23.

Journey of Islamic Economics in the Modern World. Muqorobin, Masyhudi. 2008. Makkah : Islamic Research and Training Institute - IDB, 2008. The 7th International Conference in Islamic Economics. p. 385.

Kiyosaki, Robert T. 2000. Rich Dad, Poor Dad. United State: Warner Book, 2000. Komparari Peningkatan Inklusi Kenangan dan Indikator Pembangunan di Indonesia. Akyuwen, Roberto and Mangowal, Caroline. 2017. 2017, Jurnal Modus, pp. 96-109.

Kompas. 2019. Literasi Keuangan Untuk Generasi Milenial. Ekonomi Kompas. [Online] August 10 , 2019. https://ekonomi.kompas.com/read/2018/11/22/153800926/literasi-keuangan-untukgenerasi-milenial .

Liputan6. 2019. Ojk Sebut Baru 234 Persen Anak Muda Paham Produk Keuangan. Bisnis. [Online] August 10, 2019. https://www.liputan6.com/bisnis/read/3532963/ojksebut-baru-234-persen-anak-muda-ri-paham-produk-keuangan .

Literasi Kenangan Pelaku Ekonomi Rakyat. Ma'ruf, Ahmad and Desiyana, Tasya. 2015. 2015, Buletin Ekonomi, pp. 139-270.

Muin, Idianto. 2013. Sosiologi untuk SMA/MA Kelas X. Jakarta : Erlangga, 2013.

OJK. 2016. Financial Authority Service Regulation Year 2016, Chapter 1 Article 1 Paragraph 7 and Article 11. Jakarta : Financial Authority Service, 2016.

-. Kanal. Edukasi dan Perlindungan Konsumen. [Online] Financial Service Authority. [Cited: November 11, 2018.] http://www.ojk.go.id/id/kanal/edukasi-dan-perlindungankonsumen/Pages/Literasi-Keuangan.aspx.

OJK. 2013. Strategi Nasional Literasi Kenangan Indonesia. Jakarta: Otoritas Jasa Keuangan, 2013.

OJK. 2016. Strategi Nasional Literasi Kenangan Indonesia. Jakarta: Otoritas Jasa Keuangan, 2016.

OJK. 2013. Survey Otoritas Jasa Keuangan. Jakarta : Financial Authority Service, 2013. OJK, Peraturan. 2016. Peraturan Otoritas Jasa Keuangan Tahun 2016, Bab 1 Pasal 1 ayat 7 dan Pasal 11. Jakarta : Otoritas Jasa Keuangan, 2016. 
Pemikiran Gustav Jung Tentang Teori Kepribadian (Implikasinya Terhadap Interaksi Sosial). Ismail, Feby. 2009. 2009, Jurnal IAIN Manado, pp. 1-12.

Pengembangan Modul Edukasi Literasi Keuangan Islam dan Produk Halal untuk UMKM, Sebuah Pemikiran. Wahyuni, Nur Ikka. 2016. Jakarta : s.n., 2016. Prosiding Seminar Nasional Pendidikan Ekonomi dan Bisnis.

Quarterlife Crisis: The Unique Challenge of Life in Your Twentie. Robbins, Alexander and Wilner, Abby. 2001. London : Penguin Putman, 2001.

Quarterlife Crisis: Then Unaddressed Phenomenon. M. Thorspecken, Jennifer. 2005. New Jersey : Prosiding Annual Conference of the New Jersey Counseling Association, 2005.

M.Thorspecken, Jennifer. 2005. New Jersey: s.n., 2005. Prosiding Annual Conference of the New Jersey Counseling Association. pp. 120-127.

Si, Initial. 2019. Financial Literacy. [interv.] Alfina Rahmatia. June 13, 2019.

Sugiyono. 2012. Metode Penelitian Kuantitatif, Kualitatif, dan R\&D. Bandung : Penerbit Alfabeta, 2012.

Sumanto. 2014. Statistika Terapan. Jakarta : CAPS (Center of Academic Publishing Service), 2014.

The Holistic Phase Model of Early Adult Crisis. Robinson, Oliver C, Wright, Gordon R.T. and Smith, Jonathan A. 2013 : Journal of Adult Development, Vol. 20.

The Tension Between Gender Equality and Doing Gender Swedish Couples' Talk. About The Division of Housework. Nyman, Charlott, Reinikainen, Lasse and Eriksson, Kristina. 2018. 2018, Women's Studies International Forum, p. 44.

Nyman, Charlott, Reinikainen, Lasse and Eriksson, Kristina. 2018. 2018, Women's Studies International Forum, p. 44.

Tingkat Literasi Kenangan di Kalangan Mahasiswa STIE Musi. Mendari, Anastasia Sri and Kewal, Suramaya Suci. 2013. 2013, Jurnal Economia, pp. 130-140.

Tingkat Literasi Kenangan Pada Mahasiswa S-1 Fakultas Ekonomi. Margaretha, Farah and Pambudhi, Reza Arief. 2015. 2015, Jurnal Manajemen dan Kewirausahaan, pp. 76-85. UI, Initial. 2019. Financial Literacy. [interv.] Alfina Rahmatia. June 10, 2019.

Widianto, Bambang. 2014. Keuangan Inklusif dan Penanggulangan Kemiskinan. Jakarta : National Team for The Acceleration of Poverty Reduction, 2014. 